DE DE GRUYTER OPEN
Research Article

(C) 2018 Sampson Tawiah and Frederick Ngmenkpieo. This is an open access article licensed under the Creative Commons Attribution-NonCommercial-NoDerivs License (http://creativecommons.org/licenses/by-nc-nd/3.0/).

\title{
Adult Basic Education and Training in South Africa: The Perspectives of Rural Women, in Khotso
}

\author{
Sampson Tawiah \\ PhD Candidate, \\ Department of Adult Basic Education, \\ University of South Africa \\ Frederick Ngmenkpieo \\ Research Fellow, \\ Faculty of Educational Sciences, \\ Walter Sisulu University
}

Doi: $10.2478 / m j s s-2018-0005$

\begin{abstract}
The aim of the study was to understand the perspectives of rural women in Adult Basic Education and Training (ABET), in Khotso. Rural women in the area lag behind in knowledge and skills for livelihood. The aim of ABET was to provide the educationally disadvantaged individuals, especially rural women, with knowledge and skills for livelihood in the countryside. Despite this initiative, rural women still lack skills for better living. Without basic education, these rural folks can be condemned to perpetual poverty and desolate. A qualitative research method in the form of a case study was designed to understand the issues from the point of view of the participants in context-specific settings. This qualitative design gives the authors, in-depth understanding of the phenomenon under study. A sample of sixteen women participants was purposively selected from four ABET centres. This sampling method was used to help the researchers focused on the real life situations of participants in their natural environment which delved better into their experiences. Data were collected through individual and focus group interviews. The two sets of interviews were audio recorded with the permission from the participants. Content analysis techniques were used to analyse data. The findings indicated that rural women were left desolate due to some obsolete cultural practices and perceptions. Based on the findings the paper recommends that $A B E T$ programmes should be revamped to make them more effective in terms of skills training to improve the lives of the participants.
\end{abstract}

Keywords: women empowerment, economic development, basic skills and adult.

\section{Background}

The aim of Adult Basic Education and Training (ABET) is to provide educationally disadvantaged individuals, especially rural women with knowledge and skills for socio-economic benefits. These include improved living conditions, freedom from poverty, high self-esteem, social, economic and political participation. Setoi (2012) affirms that ABET is designed to provide rural dwellers, particular women with basic knowledge and skills for socio-economic development. The authors' stress that ABET can be used to promote lifelong learning opportunities for all, especially rural women in meeting their social and economic challenges (Hanemann, 2015). However, these rural folks lack knowledge and skills for socio-economic development. Women constitute two-thirds of the world's non-literate population (UNESCO, 2014). Education for All Global Monitoring Report states that the 
majority of rural women, especially in the countryside communities lack basic education for livelihood (UNESCO, 2014). Indeed, this has been a concern for several years. The fact that rural women still lack knowledge and skills for development motivated the authors of this paper to investigate the perceptions of rural women involved in the programmes of $A B E T$.

A large number of world illiterate are concentrated in developing countries and South Africa is one of them. High literacy level is instrumental to personality development and economic emancipation (Muodumogu, 2012). In other words, illiteracy brings with it some social and economic glitches. These include poverty, low self-esteem, lack of participation in economic activities and underdevelopment. Therefore, the authors argue that the high rate of illiteracy which leads to unemployment and poverty can be reduced through basic education and skills training of rural women (Cornwall \& Brock, 2005). ABET is one of the fields of academic discipline that is trusted with the responsibility of solving the problem of rural women, especially in rural communities (Umar, Eshak, Bichi, \& Aujara, 2010). In this regard, ABET is crucial for success in the social and economic development of rural women who are concentrated in the countryside communities.

Women are to be empowered in order to achieve their dreams of gaining literacy, knowledge, and skills for social and economic freedom. For this reason, a number of high-profile literacy interventions (UNESCO, 2014) have been established specifically for women (UIL, 2013). Its aim was to ensure economic growth, social equality and environmental sustainability for all, especially women (UN, 2012). Arguably, whether or not these interventions benefited women, informs the researchers' decision to investigate and report on the perceptions of rural women involved in ABET programmes. Rural women deserve basic education to acquire knowledge, skills, and values that can enable them to cope with the everyday social milieu in which they find themselves (Ngozi \& Prince, 2011).

ABET in South Africa, is fundamental to equip rural women with knowledge and skills for livelihood, however, this area of study has been neglected. Wuraola (2014) confirms this notion that ABET has been neglected in most rural communities and this advocate for the tremendous need for literacy and adult basic education in South Africa. There are many people, women inclusive, who are unemployed and live in poverty (Mckay, 2011) because they lack basic education. Adult basic education and training is aimed to provide basic education and skills. This will help rural women live productive lives for socio-economic development (Umar et al., 2010). In this regard, ABET is seen not only as the most significant instrument for changing rural women social economic status in South Africa but as a tool for employment and socio-economic development (Tawiah \& QuanBaffour, 2017).

Research conducted and reported indicate the positive effects of ABET on South Africa's economic growth and development linked to the economic improvements in the life circumstances of its citizens. For example, Stats S.A Millennium Development Goal Country Report (2013) indicates that the country has made a lot of progress toward poverty alleviation. However, the authors of this paper argue that levels of poverty among vulnerable groups such as women and children among a rural population still remain a major challenge. Hence, acquiring knowledge and skills is crucial to provide a better life for these vulnerable groups.

South Africa is a middle-income country with high levels of poverty which is concentrated in the rural areas. This is confirmed by McKay (2011) that poverty in rural communities in South Africa, is at a high of $67 \%$ owing to the poor social and economic conditions that rural women live. For example, there is lack of basic infrastructures such as electricity, transportation, and unemployment. Without some of these basic amenities, it can be difficult for rural women to engage in economic activities of their respective communities. Adult education is one of the tools for eradicating poverty and acquiring skills for sustainable development. The Global Report on Adult Learning and Education (UIL 2013) notes that adult education is still not a priority in many countries. For instance, the Asia South Pacific Bureau of Adult Education (2012) findings show that very little of national education budgets are spent on adult education programmes. However, Mauch (2014) emphasises that Adult basic education aims to promote basic knowledge and skills for better living conditions of rural women.

Khotso a rural community in the Eastern Cape of South Africa is the area under study. It is characterised by poverty, low levels of economic activity, unemployment and high levels of 
dependency on welfare (Mayer, Gordhan, Manxeba, Hughes, Foley, Maroc, \& Nell, 2011). Education through ABET is the best means to solve the problems of rural women. This is why ABET programmes are established to provide rural women with knowledge and skills necessary for them to be gainfully employed and engage in income generating projects (Gardiner, 2008; Zuma, 2010). Research conducted shows that most rural women depend on welfare (Mayer et al., 2011) for their needs. This makes it difficult for rural women to provide financial support for themselves and their families. Therefore, government intention for ABET centres to offer literacy and employable skills to people, especially rural women and empower them to change their living conditions is vital. According to Mckay (2011), ABET programmes are meant not only to teach women how to read and write but also to empower them to be able to start their own business, engage in community projects, form groups, and forums where they will discuss their family problems and how to overcome them. It is, against this backlog of information that informs the decision of the authors of this paper to investigate the perceptions of women, especially in rural communities.

\section{Problem}

The authors of this paper share the sentiments with scholars such as Moyo (2014), that despite the introduction of Adult Basic Education and Training (ABET) and Literacy Programmes a large number of rural women in South Africa continue to live in poverty. Moyo argues that in spite of the centrality of adult basic education in the field of development, on its own, it is unlikely to effectively deal with the numerous and somewhat complex challenges that disadvantaged people, particularly rural women, are confronted with in their daily lives. Moyo (2014) affirms that challenges of rural woman demand more than just basic education. The problem is that adult education for the majority of South Africans has been seriously neglected. There is little or no investment in education and training of rural women. The questions this paper sought to answer are; are the programmes of ABET providing women with the relevant knowledge and skills for livelihood activities? What are the perceptions of women involved in ABET programmes?

\section{Objective of the Study}

The objective of the study was to understand the perceptions of women involved in the programmes of $A B E T$.

\section{Methodology}

A qualitative research approach was used to investigate the phenomena under study. This gave the researchers the opportunity to experience the real life situation of the women. This study was conducted to investigate the perspectives of rural women as they are involved in ABET programmes. Data were collected through individual and focus group interviews. The interviews were semi-structured as it provided a clear set of reliable instructions for the researchers (Cohen \& Crabtree, 2008). The researchers use probing to validate the research instruments and it allowed for better understanding that enhanced effective response (Berg, 2004). Focus group was particularly suitable for this study because it delved deeply into the experiences of participants and understand better how they feel about their involvement in ABET programmes. Data from focus group contributed effectively for information about what people think and feel about ABET activities on women.

For the purpose of accuracy, the two sets of interviews were audio recorded with the permission from 16 participants who were purposively selected for the study. The researchers use purposive sampling so that they can select suitable participants who are information rich. Maree (2007, p. 70) buttresses that sampling refers to the process used to select a portion of the population for a study. 


\section{Data Analysis}

Two sets of data were collected and analysed separately and later merged. Rabiee's (2004) framework of data analysis which provided a clear series of steps was used to help the researchers manage data much more easily. The analysis was much more on interpretation and explanation of the research participants' perspectives (Pettigrew, 2013). The analysis started during the data collection process. Thus, the researchers skillfully facilitate the discussion and generate interview data. The recorded data was later transcribed into text. In the second step, the researchers thoroughly read through the transcript to familiarise themselves more with the data. The aim was to become immersed in the details and get a sense of the interviews as a whole before breaking it into units. After this process, the researchers coded and developed categories out of which themes were formed for discussion. In the final analyses, the researchers made sense of the individual and group quotes in the discussion.

\section{Findings}

The perspectives of the women are that ABET centres in Khotso are not well resourced to provide the much-needed skills to women. Most of ABET women graduates find it difficult to be employed. This is because they lack the necessary skills for employment. More so, ABET centres are situated far away from the students. The women find it difficult to travel to and from the centres after tuitions. Most ABET women graduates in Khotso are unemployed due to skilled workforce demand for quality rural service delivery which the ABET centres do not provide for rural women. In addition, the study conducted in Khotso revealed that women are unemployed and do not have access to jobs due to a lack of relevant skills and training that they receive at the centres. Finally, ABET women find it difficult to engage in their own income generating projects because the programmes that are offered at the centres focused more on literacy and numeracy instead of job-related skills such as tailoring, catering, computing and dress making.

\section{Discussion of Findings}

\subsection{Resourcefulness of the ABET centres}

ABET centres in Khotso are important public institutions. They are learning environments, functioning primarily as skills development centres. They are available for teaching programmes, meeting space and hosting various resources (books and magazines, equipment). Though these centres are meant to provide to support and enrich identified skill deficits, the findings of this study show that ABET centres in Khotso are not well resourced to provide the much-needed skills to women. The study shows that it was difficult to get to schools in the villages and rural communities because of deplorable road conditions (Gardiner, 2008). The perspectives of the participants are that ABET centres are not good enough places for study. They have inadequate facilities and resources. They claimed:

Our classrooms where we study are in a bad condition. These classrooms are used by children, therefore, the chairs and tables are too small for us. Because the chairs are too small we sit on the tables and this makes learning difficult

From the response above, the perspective of the participants shows that there is no suitable learning space for the women involved in ABET programmes. Due to the lack of adequate resources at the ABET centres, rural women are not skilled enough for skill related jobs. According to Leibbrandt et al (2010), most rural women remain economically poor because ABET programmes have not been resourced to develop people with the needed skills for the labour market. It is only when women have the necessary employable skills that poverty can be alleviated among them. 


\subsection{Provision of the much-needed skills to women}

Although rural women have benefitted from ABET initiatives somewhere in the country, evidence from the studies highlighted in the earlier sections shows that some rural women are still skills and knowledge poor. The question that arises is: Why are these rural women still lagging behind in knowledge and skills despite the adult basic education initiatives put in place by the South African government (Moyo, 2014)? The response from a participant indicates as follows;

I think the government has done well for us by providing ABET learning centres for us. However, the ABET programme is not good for our needs. We want to learn skills that we can use to do our own work if we don't find jobs. If we can learn skills like pottery, baking, and sewing that can be good for us.

The response above indicates that $A B E T$ programmes are irrelevant to the needs of rural women. Hence, they are unable to participate in economic activities of their communities. The perspectives of the women are that computer skills training, sewing, and baking at the centres can help them to do better in life. However, they are not being provided with these important skills. This is indicated in the response below;

We are not learning practical skills for us to be self-employed. For example, in Agriculture Science, we are not taught the practical aspect that will enable us to work in our own farms to feed ourselves and to sell our products for income. We only learn the theory aspect of the subject.

The perspectives of the participants here have to do with levels of difficulty in ABET centres and the appropriateness of the curricula being offered to students. Generally, the perspectives of the women about ABET have been that the provision of the much-needed skills to women has largely been met with challenges in terms of their needs which include practical skills for livelihood activities (Umalusi, 2008).

\subsection{Employability of $A B E T$ women graduates}

Most ABET women graduates in Khotso are unemployed due to skilled workforce demand for top quality rural service delivery which the ABET centres do not provide for women. These rural folks in Khotso have completed ABET programmes, but sadly, evidence from the studies show that they are still unskilled and knowledge incompetent for employment.

I think the government has done well for us by providing ABET learning centres for us. However, the ABET programme is [are] not good for our needs. We want to learn skills that we can use to do our own work if we don't find jobs. If we can learn skills like pottery, baking and sewing that can be good for us.

Moyo (2014), states that adult basic education and training skills are crucial pieces of the development puzzle of women, though, the absence of community platforms make both adult basic education and the skills development aspects lack significance to poor communities. Moyo, therefore, suggests that community needs and skills be taken into account, thus, needs of specific groups of people in a specific environment like those in Khotso be considered. Rural people have their own needs and goals as such women are to be given a voice to participate in decision making that concern their development (Moyo, 2014, p.1).

\subsection{Location of the ABET centres}

ABET centres are situated far away from the students. The women find it difficult to travel to and from the centres for and after tuitions. They claim the centres are situated very far from them in this way;

The centres are situated very far from us and we do not have money to go there every day. 
Sometimes we don't go for classes because we are unemployed and as such don't have money for transportation.

The above response indicates that the strategic location of ABET centres has brought negative financial constraints to the students and parents. Many of the students have to travel a considerable distance to get to the centre for studies and that may hinder their learning time. The amount of learning time is very crucial to student achievement because students enter into the learning setting with diverging levels of knowledge. The point is that the amount of time actually the student spent in the classroom has a direct correlation to a student's success in education (Babyegeya, 2002). The establishments of ABET centres far away from the users (women) means that they may go to class late, skips class or be absent for classes.

\subsection{Nature of courses offered at ABET centres}

Another perspective was that ABET women graduate ought to be engaged in their own projects to generate income. However, rural women find it difficult to do so because the programmes that are offered at the four centres focused more on literacy and numeracy instead of job-related skills such as tailoring, cooking, computing, and dress making. A study by FHISER and DRA (2006) show that rural households spend most of their income on food, and there is clear evidence of growing food insecurity, as measured by the number of meals consumed and the quantity and variety of foods eaten (FHISER \& DRA, 2006). Therefore, it is clear that rural women require practical skills in Agriculture to provide food and to generate income for them to survive. A participant expresses her sentiment in this way;

We are not learning practical skills for us to be self-employed. For example, in Agriculture Science, we are not taught the practical aspect that will enable us to work in our own farms to feed ourselves and to sell our products for income. We only learn the theory aspect of the subject.

This response shows that the women do not have access to the much-needed courses and skills at the centres which made skills development and accessibility at ABET programmes very difficult. Considering the plight of rural women, one would have thought that the ABET programmes would direct more attention to teaching or training women on growing food and case crops in the rural area which can contribute significantly to household income. In other words, they should have more on skill development on crop production, animal husbandry, gardening and other entrepreneurial skill development just to empower the rural folk especially women to be selfdependent. Baatjes and Baatjes (2008) argue that if adult basic education refers to all forms of organised education and training that meet the basic learning needs of adults, including literacy and numeracy to develop their capacities, make informed decisions, then what rural women are receiving is not enough. This shows that ABET programmes should be directed towards providing rural women with job-skills for better living conditions.

\section{Conclusion}

The aim of the study was to understand the perspectives of rural women as they are involved in ABET programmes. The findings of the study clearly indicate the perspectives of the women, in that ABET centres, are poorly resourced which makes learning difficult. The women are not provided with knowledge and skills for livelihood ventures. Most of the women who graduated from ABET programmes are unemployed because they do not have relevant skills for employment or to be selfemployed. Access to ABET centres is difficult because of its location and the deplorable roads in rural communities. The nature of ABET courses is inadequate for the needs of the women. This makes it difficult for women to benefit from the programmes provided by the institution.

\section{Recommendations}

Based on the findings that emerged from the study, the authors of this paper made the following 
recommendations that;

- ABET programmes, as well as facilities, should be revamped to make them more effective in terms of skills training to improve the lives of the women in the Khotso rural areas.

- Women should be given a voice in which they air their views on the designing of ABET curriculum to suit their needs.

- Curriculum designers of ABET programmes should do needs analysis before designing new programmes.

\section{References}

ASPBAE (2012). The power of literacy: women's journeys in India, Indonesia, Philippines and Papua New Guinea, Manila: ASPBAE

Baatjes, B \& Baatjes, I, (2008). The Right to Adult and Community Education. Centre for Education Rights and Transformation.

Babyegeya, M. (2002) .Educational Planning and Administration. Dar -es- salaam. Open University of Tanzania. Berg, B., L. (2004). Qualitative research methods: for the Social Sciences. Boston, California.

Cohen D, Crabtree B. (2008). "Qualitative Research Guidelines Project." July 2006. http://www.qualres.org/HomeSemi-3629.htm

Cornwall, A. \& Brock, K., 2005. What do buzzwords do for development policy? A critical look at 'participation','empowerment'and 'poverty reduction'. Third world quarterly, 26(7), pp.1043-1060.

FHISER \& DRA (Fort Hare Institute of Social and Economic Research and Development Research Africa), (2006). Rapid Eastern Cape Provincial Assessment of Service Delivery and Socio- Economic Survey. FHISER, East London.

Gardiner, M. 2008. Education in Rural Areas. Issues in Education Policy Number 4. Center for Education Policy Development (CEPD), Johannesburg, South Africa. From http://www.cepd.org.za/files/pictures /Education\%20in\%20Rural\%20Areas202008.pdf (Retrieved on February 5, 2013).

Hanemann, U. (2015) Lifelong literacy: Some trends and issues in conceptualising and operationalising literacy from a lifelong learning perspective

Leibbrandt, M., J. Levinsohn, \& J. McCrary. (2010). Incomes in South Africa after the fall of apartheid. Journal of Globalization and Development 1(1)

Maree, K. (2007). First steps in research, printed and bound by parlprint, Oosterland Street, Dal Josafat, Paarl, South Africa.

Mayer, M. J., Gordhan, S., Manxeba, R., Hughes, C., Foley, P., Maroc, C., \& Nell, M. (2011). Towards a youth employment strategy for South Africa. Development Planning Division working paper series, (28).

McKay, V.I (2011). The South Africa Kha Ri Gude Mass Literacy Campaign: Study Guide for ABT 1525. Department of Adult Basic Education and Training, Pretoria: University of South Africa.

Moyo, C.S., 2014. Active participation of rural women in developmental issues: Poverty alleviation lessons for South Africa. Gender and Behaviour, 12(1), pp.5994-6001.

Muodumogu, C.A. (2012) Literacy Needs of Non-Literate Women in Benue State of Nigeria. International Journal of Social Sciences and Education, 2(2), 176-185

Ngozi, E.M \& Prince, O.F.E.O, (2011). Challenges of women participation in continuing higher education programme: Implications for adult women counselling and education. Edo Journal of Counselling 4(1\& 2): $130-143$

Pettigrew, A.M., 2013. The conduct of qualitative research in organizational settings. Corporate Governance: An International Review, 21(2), pp.123-126.

Rabiee, F., 2004. Focus-group interview and data analysis. Proceedings of the nutrition society, 63(4), pp.655-660.

Setoi, M., 2012. Youth and adult learning and education in Lesotho. Open Society Initiative for Southern Africa (OSISA).

Stats, S.A., 2013. Millennium development goals country report. Pretoria, South Africa: Statistics SA.

Tawiah, S. \& Quan-Baffour, K.P. (2017) Education is power: Adult and Community Education and Training as an employment tool for women in Lusikisiki. Proceedings of the South African International Conference on Education 2017. pp. 70-77.

UIL (2013) Literacy programmes with a focus on women to reduce gender disparities. Case studies from UNESCO Effective Literacy and Numeracy Practices Database (LitBase), Hamburg: UNESCO Institute for Lifelong Learning http://www.unesco.org/uil/litbase/

Umalusi (2008). The state of national curricula for Adult Basic Education \& Training: Letting a thousand flowers bloom or a disaster of decentralization?. Pretoria: Umalusi

Umar, F.M., Eshak, A.M., Bichi, A.A., \& Aujara, I.W. (2010). Trends in adult and non-formal education in Maiwada, D.A. \& Yakasai, M.I. (ed) Trends in education research. Zaria. ABU Press 
UN (2012) Resilient People Resilient Planet: A future worth choosing, the report of the UN Secretary-General's High-Level Panel on Global Sustainability, January 2012

UNESCO (2014) EFA Global Monitoring Report 2013/4, Teaching and Learning: Achieving quality for all (Summary Report), Paris: UNESCO

Wuraola, A.C (2014). Implementing vocational skills training among rural women for equal access to qualitative education. International. Journal of research and review in education. 1:7-10.

Zuma, J. 2010. State of the Nation Address. From <http://www.info.gov.za/speeches/2003/0302141> (Retrieved on May 12, 2013). 